\title{
Change of Foreign Operation Method Impetus and Switching Costs
}

Pedersen, Torben; Petersen, Bent; Benito, Gabriel R. G.

Document Version

Final published version

Publication date:

2000

License

CC BY-NC-ND

Citation for published version (APA):

Pedersen, T., Petersen, B., \& Benito, G. R. G. (2000). Change of Foreign Operation Method: Impetus and Switching Costs. The Link Program. LINK Working Paper No. 2000-25

Link to publication in CBS Research Portal

\section{General rights}

Copyright and moral rights for the publications made accessible in the public portal are retained by the authors and/or other copyright owners and it is a condition of accessing publications that users recognise and abide by the legal requirements associated with these rights.

Take down policy

If you believe that this document breaches copyright please contact us (research.lib@cbs.dk) providing details, and we will remove access to the work immediately and investigate your claim. 


\title{
Change of Foreign Operation Method: Impetus and Switching Costs
}

\author{
Torben Pedersen* \\ Copenhagen Business School \\ Bent Petersen** \\ Copenhagen Business School \\ Gabriel R.G. Benito*** \\ Norwegian School of Management BI
}

\section{Keywords}

Entry modes, switching costs, internationalization process

\section{Acknowledgements}

We thank the anonymous reviewers, Harald Biong, and Myles Shaver for their very helpful comments, Kim Vasant Nielsen for excellent research assistance, and Vibeke Henriksen for editorial assistance. Previous versions of this paper have been presented at the Academy of Management Annual Meeting, San Diego, August 1998, the 23rd EIBA Annual Conference, Stuttgart, December 1997, and in seminars at University of Vaasa, Swedish School of Economics, Norwegian School of Economics and Business Administration, Norwegian School of Management BI, and at the University of Melbourne. We thank participants at these meetings and seminars, in particular Ingmar Björkman, Andrew Delios, Carl Fey, Karin Fladmoe-Lindkvist, Mats Forsgren, Jean-Francois Hennart, Jan Johanson, Heli Korhonen, and Stephen Nicholas for their many comments and suggestions.

* Torben Pedersen, Professor, Department of International Economics and Management, Copenhagen Business School, Copenhagen, Denmark.

** Bent Petersen, Associate Professor, Department of International Economics and Management, Copenhagen Business School, Copenhagen, Denmark.

*** Gabriel R. G. Benito, Professor, Department of Strategy, Norwegian School of Management BI, Sandvika, Norway. 


\title{
Change of Foreign Operation Method: Impetus and Switching Costs
}

\begin{abstract}
This paper explores what factors motivate exporters to change their foreign market servicing mode from using independent distributors and agents to setting up their own local sales organization, and what factors impede such changes (switching costs). Using data from a sample of 214 Danish exporters, of which 32 had changed their foreign operation method between 1992 and 1997, the analysis shows that switching cost factors are indeed of particular importance in order to explain the incidence of such changes.
\end{abstract}

\section{INTRODUCTION}

The choice of an appropriate entry mode is one of the most important decisions that companies have to make when they expand business activities beyond the borders of their home country (Root, 1987). Operating in a turbulent environment the companies by no means have proof guarantee that an entry mode decision once made will remain as the best way of servicing a foreign market. Also, the companies themselves evolve over a period of time and as they grow bigger and get more experienced, barriers to high-commitment operation methods tend to diminish. However, the economics literature on foreign operation methods is basically static and has only little to tell about changes of the initial entry mode. How often do companies change mode of entry? What induces changes? What impedes changes? So far, international business scholars have paid only modest attention to these crucial questions. This study focuses on one particular entry mode change, namely the transition from an entry mode of using foreign, independent intermediaries (i.e. local sales agents or distributors) to setting up an employee salesforce, thereby conducting the marketing activities "in-house".

Why do some exporters decide to change their foreign method of operation? The literature on foreign market entry mentions a number of factors that influence firms' preference for certain operation methods when entering a given foreign market (see e.g. Benito and Welch, 1994). Changes in external and internal conditions may, however, over time make the initial mode of operation less appropriate. Assuming that the decision makers do not lack information about the factors that affect the optimal foreign operation method, they should therefore respond if a particular mode becomes inappropriate. However, while change-inducing factors certainly are important, such a description of mode changes seems one-sided, 
since it ignores that - as the other side of the coin - several factors could also make changes difficult to implement, or even, from an economic perspective, poorer alternatives in the first place. Such factors, which can broadly be termed switching costs (Weiss and Anderson, 1992), have so far largely been overlooked in the international business literature (Benito et al., 1999). The aim of this paper is to develop and test a conceptual model that can predict when exporters will convert their foreign intermediaries into an employee salesforce and which exporters will continue with their initial mode of entry. Our assertion is that such changes should happen inasmuch as the benefits of substituting the existing operation method more than offset the anticipated switching costs. The paper is organized as follows. The next section reviews the extant literature on mode shifts. The conceptual model is developed in section 3, which also presents the hypotheses. Section 4 describes the sample, the data collection procedure, and the operational measures used in the study. Section 5 reports and discusses the results. A conclusive section 6 closes the paper.

\section{LITERATURE REVIEW}

Entry mode decisions have attracted wide interest among international business scholars (see e.g. Anderson and Gatignon, 1986; Hill, Hwang and Kim, 1990; Benito and Welch, 1994; Madhok, 1997). The economic-strategic literature on foreign operation methods has largely taken for granted that whenever a choice is made, it will be the most suitable one given the circumstances. Thus, the firm will consider a change of mode only if drastic changes occur. Also, even if a need for adjustments to the initial entry mode would occur at some later stage, it is often assumed that changing to another market servicing mode is difficult and costly. As stated by Anderson and Coughlan (1987, p. 71) in their study of the choice between independent foreign intermediaries and sales subsidiaries: "Channel choices, once made, are often difficult to change.”

Another stream of research has taken a behavioral or "process" perspective, highlighting the incremental aspects of firms' international expansion due to bounded rationality, organizational problemsolving, and availability of resources and capabilities (Johanson and Vahlne, 1977; Welch and 
Luostarinen, 1988). Empirical studies starting out from this perspective have in particular analyzed the sequence of operation methods used by firms at varying points in time (see e.g. Johanson and Wiedersheim-Paul, 1975; Björkman and Eklund, 1996). Although “anomalies” are not infrequent (see e.g. Hedlund and Kverneland, 1985), the findings of several studies largely support the notion of a gradual development of commitment to foreign operations over time (Welch and Luostarinen, 1988).

In contrast to the dominant economic-strategic school, the internationalization process approach recognizes changes of foreign operation mode as commonplace and something to be expected given the nature of the internationalization process itself. Decision-makers' perceptions of the costs, risks, and benefits of being involved in a market change as they learn more about that market. As a result, firms should be expected to move from one type of operation method to another - from modes involving low levels of commitment to modes of higher commitment - as they gain experience in a particular market. However, because its emphasis is on organizational and individual drivers and facilitators of change, the “process” perspective has little to say about what might impede changes.

Many studies conclude that firms often start their operations into a foreign market by using local agents (for a review, see Leonidou and Katsikeas, 1996). Sometimes, the initial mode of entry may persist. Rosson (1987) followed 21 relationships between Canadian manufacturers and their independent distributors in the U.K. While several relationships were terminated or regressed to occasional exports during the observed 7-year period (1978 to 1985), only one conversion to own sales force took place, and this change was induced by the market development created by the distributor. However, there is also some evidence that firms, over time, decide to substitute local agents for their own sales organization. For example, in a case study of the pharmaceutical company UpJohn, Fina and Rugman (1996) report that while this company had usually entered new markets with an agreement with a local distributor or agent, in a majority of markets it had later on shifted to other modes such as setting up its own sales office.

Few studies exist on the determinants of mode shifts. Using data from the Harvard Multinational Enterprise Project, Gomes-Casseres (1987) examined 419 conversions from international joint ventures to wholly-owned subsidiaries undertaken by US multinationals over the period 1900-1975. His study suggested that in some cases changes took place mainly because the initial choice of foreign operation 
method turned out to be unsatisfactory, or even plainly mistaken. More frequently, however, the transition to wholly owned subsidiaries was induced by a need to adapt to changing circumstances. Specifically, the study pointed out four main motives for changing to wholly-owned subsidiaries: 1) the MNCs' accumulation of knowledge about local business conditions, 2) the MNCs' increasing international experience in general, 3) economic growth in the host country, and 4) change of local government policy on foreign ownership.

The empirical studies by Calof (1993), and Calof and Beamish (1995) provide interesting insights into the various stimuli to international mode shifts. Looking at 100 and 139 mode shifts, respectively, undertaken by Canadian (Ontario-based) companies between 1980 and 1990, the two studies identify a number of (interplaying) corrective and adaptive stimuli to mode shifts. Corrective stimuli were: 1) underestimation of exporting costs, 2) misjudgment of local demand, and 3) incompatibility with the company's growth objectives. The adaptive stimuli comprised organizational, relational and external changes. Organizational stimuli comprised change of management market commitment along with acquisition of local market knowledge, new diversification strategy, financial strengthening, and new company management with a different commitment to international business. Relational changes consisted of extreme performance (either in a negative or a positive direction) of the current mode; with almost the same frequency did good and bad performance bring about mode shifts. Finally, new trade area regimes (Europe 1992) was an external change stimulus.

While studies of the motives for changing foreign operation method are relatively rare, so far, to the best of our knowledge, no studies have been conducted about factors that might impede such changes. Interestingly, despite its potential central role as a determinant of choice of operation mode as well as for change of mode, the concept of switching costs has yet to have been discussed in-depth in the international business literature (Benito et al., 1999). In fact, although previous analyses of related concepts can be found, such as consumer switching costs (Klemperer, 1987), barriers to exit (Caves and Porter, 1977), obstacles to change and expansion (Penrose, 1959), and structural inertia (Hannan and Freeman, 1984), these concepts have generally received little attention so far in the economics and management literature. Clearly, the reviewed empirical studies say little about the potential costs associated with international 
mode shifts. Lack of empirical evidence regarding the costs of switching foreign operation modes led us to turn to the seminal study by Weiss and Anderson (1992), who conceptualize switching costs in a purely domestic context. Examining the intentions of U.S. electronic manufacturers to convert (domestic) representatives into employee salesforces, they model the likelihood of intended conversions as determined by impetus to change factors on the one hand, and perceived switching costs on the other. Weiss and Anderson (1992) operationalize switching costs into set-up costs and take-down costs. While their data suggest that perceived set-up costs impede an otherwise attractive conversion, the effect of takedown switching costs was found to be insignificant.

\section{CONCEPTUAL FRAMEWORK AND HYPOTHESES}

What determines the likelihood of an entry mode shift? It is useful to group the potential determinants into three main categories ${ }^{1}$. The first group of influencing factors are the change motivators. Although entry mode choices are made on the basis of actual and anticipated circumstances as perceived by the decision makers at the time of entry, internal as well as external factors may change considerably, sometimes in even rather unforseen ways, so that the current operation methods become inappropriate. The second group of influencing factors pull in the opposite direction; what impediments do the decision makers at a certain point in time associate with a switch from one mode to another? According to Weiss and Anderson (1992), such factors can be labelled switching costs. The third group consists of factors that, from the outset, may have affected the entry mode in a negative way. For example, difficulties in evaluating a foreign intermediary exist from the first day of entry, and such difficulties are likely to persist. As pointed out by Hennart (1991), employees are less inclined to "cheat” than outside agents. Whereas employees are paid for following instructions, the income of outside agents depends on their output, i.e. the sales they achieve in their market ${ }^{2}$. The monitoring problems associated with relying on outside agents therefore

\footnotetext{
${ }^{1}$ The analysis in this paper deals only with conversions from intermediaries to in-house operations, but the conceptual framework is a general one and could be applied to switches that go in the opposite direction, i.e. replacing in-house operations with intermediary arrangements. We thank an anonymous reviewer for pointing out this symmetry in the reasoning.

${ }^{2}$ Agents are therefore likely to concentrate on marketing activities that have an immediate impact on their revenues ("hard-selling"), rather than spending time and effort on activities with a less distinct link to actual
} 
provide a permanent incentive to internalize the foreign business activities. In addition to monitoring problems, other factors may also speak against servicing a market through independent intermediaries. For example, large sales potential and/or abundant company resources suggest that using an independent intermediary may have been a mistaken choice in the first place. In this study we are principally interested in the effects of switch motivators and switching costs. Other factors are therefore included mainly as controls.

\section{Impetus To Switch: The Change Of Circumstances Since Initial Entry}

An exporter's decision of whether to serve a foreign market through an intermediary or an employee salesforce cannot be taken once and for all. As the exporting company, the intermediary, or the foreign market change what is an appropriate operation method will also change. Thus, even exporters that initially "correctly" appointed a local intermediary may find that changing circumstances have made an employee salesforce preferable. Several switch motivators have been suggested in previous studies.

Diminishing satisfaction with the foreign intermediary. At the time of appointment, an exporter will expect the performance of the foreign intermediary to be at a certain (i.e. satisfactory) level. If an exporter is dissatisfied with the intermediary's performance at a later point in time, this would suggest that the relationship between the two parties has taken a negative direction; in fact, according to Anderson and Narus (1990), Stern and El-Ansary (1992), and Shamdasani and Sheth (1995) dissatisfaction in channel relationships is a fundamental reason for change. Calof and Beamish (1995) also report that poor performance over a prolonged period is an important reason for foreign mode shifts. Hence,

$\mathrm{H}_{1} \quad$ Exporters are more likely to switch to an "in-house” salesforce the more the satisfaction with their foreign intermediary has diminished since entry.

sales, such as providing customer service (Anderson and Oliver, 1987). In general, the performance of agents with regard to such activities is hard to measure, and requires information beyond that given by sales figures 
Exporter's accumulation of market knowledge. According Johanson and Vahlne (1977), decision makers tend to perceive market risk as being high whenever they lack knowledge about a foreign market. The uncertainty regarding market conditions tends to restrict their choice of entry mode to lowcommitment arrangements such as foreign intermediaries (Welch and Luostarinen, 1988). Over time, exporters gradually accumulate market knowledge: partly because information flows as a result of their interaction with intermediaries, but also by more actively seeking it through visits to the foreign markets. Even though the accumulation of market knowledge may occur at a decreasing rate (Barkema, Bell and Pennings, 1996), as exporters become more knowledgeable about a foreign market the attraction of highcommitment operation methods should increase. Therefore,

$\mathrm{H}_{2} \quad$ Exporters are more likely to switch to an "in-house” salesforce the more knowledge about the foreign market they accumulate since entry.

Export market growth. The appropriateness of an entry mode also depends on the expected sales volume in the foreign market in question (Buckley and Casson, 1985). Klein, Frazier and Roth (1990) show that sales volume in the export market functions as an important discriminating factor in the choice between foreign distributors, sales agents, and sales subsidiaries and home-based salesforces. While a small sales volume favors foreign intermediaries vis-à-vis employee sales arrangements, unexpectedly high growth rates in the export market should enhance the opportunity for "going direct". Hence,

$\mathrm{H}_{3} \quad$ Exporters are more likely to switch to an "in-house” salesforce the higher the economic growth of the foreign market has been since entry.

Growth of exporting company. High-commitment entry modes are resource demanding both in terms of financial means and managerial capacity (Ali and Camp, 1993; Penrose, 1956; Welch and Luostarinen, alone.The exporting company may therefore need to inspect the behavior of foreign agents, obviously at a cost. 
1988). Other things being equal, a small company cannot be expected to possess the amount of financial and managerial resources available to large companies. While most companies are small at the time they start exporting, firms that experience considerable growth subsequent to the initial market entry may, over time, start considering a wider range of foreign operation methods. Therefore,

$\mathrm{H}_{4} \quad$ Exporters are more likely to switch to an "in-house" salesforce the more the companies have grown since entry.

\section{Impediments to Switch: Perceived Switching Costs}

The concept of switching costs refers to difficulties - or costs - in changing the current behavior of firms, for example regarding their foreign methods of operation. According to Weiss and Anderson (1992), switching costs fall into two types. Take-down costs refer to the costs and revenue losses incurred by dismantling an existing foreign operation. The typical case is severance payment to a terminated foreign sales agent. Another take-down cost is the potential loss of local sales due to customers' loyalty residing with the distributor rather than the producer. Set-up costs are the costs and revenue losses of setting up a new foreign operation. They include the expenses related to recruiting and training new personnel in connection with the establishment of a sales subsidiary, as well as foreign operation learning costs (Benito et al., 1999). While the existence of set-up costs is in accordance with the internationalization process model, possible take-down costs are ignored.

Contractual restrictions (severance payment to intermediary). One obstacle in exiting from a relationship with a foreign intermediary can be the nature of the contract (Root, 1987; Rosson, 1984). Some contracts include clauses that make termination difficult to the exporter (or to both parties), in particular a long period of notification or a stipulated right to compensation upon termination (severance payment). Hence, 
$\mathrm{H}_{5} \quad$ Exporters are less likely to switch to an "in-house” salesforce the more restrictive (protective) the intermediary contracts are in terms of termination.

Loss of local sales revenue. The potential loss of local sales revenue as a result of customer loyalty residing with the terminated local intermediary may also constitute a take-down cost (Corey, Cespedes and Rangan, 1989; Heide and John, 1988). Local customers will often identify the export product with the local sales and service organization rather than with the manufacturer (exporter). If the terminated intermediary manages to replace the product(s) of the exporter with close substitutes, there is a considerable risk that many of the customers will stick to the intermediary. This is especially likely to be the case for industrial products, whereas consumer products with established trademarks tend to create more customer loyalty towards the exporter. Therefore,

$\mathrm{H}_{6} \quad$ Exporters are less likely to switch to an "in-house" salesforce the more the loyalty of the local customers resides with the intermediaries.

Recruitment and training costs. It can be difficult for the exporter to take over the experienced staff of the terminated intermediary (Corey, Cespedes and Rangan, 1989; Jackson, 1985). New marketing personnel may therefore need to be identified and recruited either among existing employees or from the outside. Also, the marketing activities to be carried out in the foreign market often require extensive training. In addition to the direct outlays related to such training, revenue losses must also be expected until the new staff has attained an adequate performance level. Hence,

$\mathrm{H}_{7} \quad$ Exporters are less likely to switch to an "in-house" salesforce the higher the recruitment and training costs involved in establishing their own sales force.

Foreign operation learning costs (exporters' lack of international experience). Being a novice in 
international business an exporter must expect to make several initial failures (Ali and Camp, 1993; Welch and Wiedersheim-Paul, 1980). The probability of failure is likely to increase whenever the action represents a fairly large step into the unknown, such as when a company choses to "go direct" rather than using local agents. Therefore,

$\mathrm{H}_{8} \quad$ Exporters are less likely to switch to an "in-house" salesforce the higher the estimated foreign operation learning costs.

\section{Effects of Other Variables}

In addition to the factors mentioned above, the literature on foreign operation methods points out several other factors that may also influence how companies choose to serve foreign markets. While not of prime interest to this study, such factors should be controlled for. First, it is generally difficult to exercise control over foreign intermediaries, and the difficulties in monitoring the performance of the intermediary may work in disadvantage of this entry mode (Anderson and Gatignon, 1986). Second, expected sales volume can be an important determinant of entry mode choice. All else equal, poor sales prospects should favor the use of local intermediaries over employee sales organization, since the intermediary can spread the marketing costs on lines of several principals/manufacturers and thereby reap economies of scope (Klein, Frazier and Roth, 1990). Third, the degree of commitment to foreign operations depends on the amount of resources available to the firm (Ali and Camp, 1993; Welch and Luostarinen, 1988). The more resources available, the stronger the ability to serve foreign markets through high-commitment modes such as setting up own sales forces. Fourth, the amount of switching costs may vary depending on the type of product; for example, customer loyalty towards exporters can be expected to be larger in the case of consumer products with established trademarks than for industrial products. Accordingly, the potential for loss of local sales revenue should be less for consumer products than for industrial products. Finally, cultural and geographical distance may affect the amount of switching costs. When operating in culturally similar countries, exporters should face lower costs with regard to recruiting and training since knowledge about these tasks to some extent is transferable (and easier to access) across close countries. In the same vein, 
shorter geographical distance should make it easier to monitor a foreign staff and thereby reduce such problems.

\section{METHOD: SAMPLE, DATA COLLECTION PROCEDURE, AND ESTIMATION}

In order to test the hypotheses, we use data on foreign operation methods measured at two different points in time, 1992 and 1997. Also, the analysis is based on data covering actual switches. These two features of our data make this study unique. Compared to the study undertaken by Weiss and Anderson (1992), where the analysis was based only on intended switches, our approach is arguably better. Moreover, because Weiss and Anderson (1992) collected their data on the response variable (intention to switch or not) and on the explanatory variables at the same point in time, it becomes nearly impossible to determine the direction of the effects; for example, did the effect go from dissatisfaction with current rep to intention to switch, or did the fact that the companies intended to switch in the near future affect their assesment of the current rep? In sum, the advantage of the present study is twofold; we use data measured at two points in time where the explanatory variables are measured before the foreign operation method is at risk of changing, and we look at actual switches rather than just intentions.

Data were collected in two steps. The first step was to collect data about the actual foreign entry modes on the particular foreign markets, and to map the respondents' perception regarding various issues related to the possibilities and problems of switching entry mode. The collection of these "pre-switch" data was conducted in 1992. The next step was taken in 1997, when data was obtained about the occurrence of switches of foreign operation method. The "post-switch" data basically consist of information on changes, if any, in the foreign operation method on the particular markets since 1992.

\section{Step 1: The Pre-Switch Data}

Data were collected in a survey of Danish manufacturing companies with export activities. Companies that in 1992 had only quite limited experience with exports (i.e. they exported to neighbouring countries only) or had equity below 15,000 US\$ were excluded from the sampling frame. After exclusion of these small 
and inexperienced exporters, a total population of 1,365 companies appeared. In 1992, the identified export managers, or as a second choice managing directors, of all companies in this population received a detailed, mailed questionnaire. Prior to distribution, the questionnaire had been tested in two rounds - with an intermediary revision - on the export managers of two companies. Before answering the thirty questions included in the questionnaire, the companies were asked to select one export market which had been served by an independent intermediary over a continuous period of at least one year. In those cases where several export markets fulfilled the criteria, the respondents were asked to choose the market representing the largest sales potential (see Petersen (1996) for a more detailed discussion of the selection criteria). Usable replies from 349 companies were received ${ }^{3}$.

\section{Step 2: The Post-Switch Data}

In 1997, the 349 companies were again contacted for a telephone interview on possible changes since 1992 in the operation mode on the particular foreign market. Most of the interviewed persons were export managers responsible for the activities on the particular market. The aim of the interviews was to check whether the Danish exporter still served the foreign market in 1997 via an independent intermediary, or whether it had changed the entry mode on the particular market. In case they had changed the entry mode, we asked the respondents to list all changes of operation mode on the market from 1992 to 1997. For various reasons we had to exclude 60 companies from the initial sample of 349 companies. The final sample consists therefore of 276 companies ${ }^{4}$.

\section{Entry Mode Shifts in the Final Sample from 1992 to 1997}

Table 1 shows changes of operation mode from 1992 to 1997. The data provides interesting information

\footnotetext{
${ }^{3}$ For these 349 companies the data base consists of basic information about the Danish exporter (such as total sales, number of employees, and industry), as well as more specific data on the activities on the particular foreign market where the Danish exporter was served by an independent intermediary. Included were data on the relationship between the Danish exporter and the foreign intermediary (such as the type of contract, remuneration, and termination rules), and a range of questions about the Danish exporter's perception of the foreign market (for example, competition, and sales potential) and the effort of the foreign intermediary.

${ }^{4} 23$ of the Danish exporters had been liquidated or merged since 1992, and in 15 cases sales to the particular market had ceased. In 22 cases we had no information about which market the original questionnaire covered, which made it impossible to check changes of market servicing method. The corrected sample was then 289 companies. Among these companies only 7 refused to answer, but in 6 other companies we could not get in touch with the right person.
} 
about the frequency of switches of operation mode: 182 companies, or two thirds of the 276 companies, were served by the same intermediary in 1997 as they were in 1992. However, the remaining 94 companies had made some kind of change since 1992 in how they served the particular market. Of these, 48 companies had shifted to a new intermediary or established their own sales organization alongside the independent intermediary in the foreign market ("dual distribution").

"Real" switches of operation mode had been implemented by 36 companies. Nearly all of these switches were from an independent intermediary to own sales organization (i.e. sales subsidiary, local sales office, or home-based salesforce), thereby "internalizing” the sales and marketing activities in the foreign market. Moreover, an additional 10 companies indicated that they intended to switch their entry mode in the near future.

All in all, during the last five years 17 per cent of the companies (46 companies) had switched, or were soon to switch their entry mode in the particular market, and a further 17 per cent of the companies (48 companies) had shifted to a new partner (intermediary) or established dual distribution. Hence, the data show that changes in entry mode and shifts of foreign partner are far from infrequent occurrences.

****Table 1 about here****

Different impetus to change should be expected to determine whether an exporting company just makes a shift of foreign partner or whether the operation mode itself is changed. In the former case, one would expect the motivation for changing to be very much related to diminishing satisfaction with the actual intermediary, and not necessarily to other changes in internal and external conditions. In the latter case, the impetus to change should be expected to be a broader range of changes in conditions (including deteriorating satisfaction with the intermediary, as well as increased market knowledge and growth in the sales potential). Thus, while the companies may only choose to shift their foreign partner in the former case, it seems probable that they would go further and switch even the operation mode itself in the latter case. 
In the present analysis, we have chosen to focus on the two most extreme groups of companies; those that were served by the same intermediary in 1997 as in 1992, and those that had made a fundamental switch of operation mode (i.e. they had "internalized" their foreign marketing activities). Companies that had made only minor changes or had intentions to do so, were therefore excluded from the analysis. This gives us a total of 218 companies split into two consistent groups: 182 companies without any shifts, and 36 companies with a complete switch of operation mode. However, due to missing values, 4 cases had to be excluded from the statistical analysis, hence bringing the number of observations down to 214. The geographical distribution of the cases is shown in table 2: a clear majority of the operations are in Europe which is not surprising given that these markets generally are the main markets for Danish exports. Although operations in the Nordic countries exhibit the lowest "switching rate" - only 2 (or six per cent) of the 33 Nordic intermediaries had been replaced by "in-house” marketing operations - there is, however, no clear pattern between the proximity of the markets being served and "switching rates". The "switching rates" for markets outside Europe are roughly the same as those for European markets.

****Table 2 about here $* * * *$

\section{Operationalization}

The variable "Satisfaction with intermediary" was constructed on the basis of three items. The companies were asked three questions: How does the company perceive the success of the intermediary in terms of i) market penetration, ii) profitability of export, and iii) the effort made? All three items were measured on a 7-point Likert scale. The three items were then added to one single variable. Cronbach’s coefficient alpha for this variable is 0.83 .

Following other studies on firms' internationalization process (Welch and Luostarinen, 1988), the time spent in a particular foreign market was used as a proxy for "accumulation of market knowledge". This variable was measured as the number of years since the company made the first agreement with the particular foreign intermediary. The variable was entered in logarithmic form in order to capture the decreasing rate of knowledge accumulation. 
The two variables "growth of market" and "growth of company" were both based on secondary data. The growth rate of GNP in the foreign market was used as a proxy for market growth. Clearly, this is a rough proxy covering the general development in the foreign country and not the growth in the market of the particular product per se. Unfortunately, it was not possible to get a more disaggregated, and hence better, measure of market growth. The growth of the company was measured in terms of employment growth. Both growth variables were measured from 1991 to 1995. A lagged specification (one year lag) was used because it is reasonable to expect a certain timelag until changes in the growth rates affect decisions on foreign operation method.

”Contractual restrictions" were measured straightforward as the period of time the intermediary should be notified in advance in case of termination of the agreement. Whether the foreign intermediary was taking care of after-sales activities was used a as proxy for "loss of sales revenue”. Following Heide and John (1988), the argument is that the more service the foreign intermediary is offering the customers, the more the customers are dependent on the intermediary, and as a result, the larger the loss of sales revenue in case of entry mode switching.

As in Weiss and Anderson's (1992) study, the companies were asked directly about their assessments of the "potential costs of hiring, recruting and training” its own sales force for the foreign market. The share of total turnover sold on the Danish home market was used as a proxy for "lack of international experience”.

Finally, the control variables were measured as follows. In order to capture "monitoring problems” respondents were asked to assess the extent to which their companies found it difficult to control the effort of their foreign agents (a 7-point Likert scale was used). GNP and number of employees were used as proxies for the control variables “market potential” and “company size”, respectively. Based on the ISIC industry classification of the Danish exporter, the type of product - either consumer or industrial - was captured by a dummy variable "product type”. The Kogut-Singh index (Kogut and Singh, 1988) was used to measure cultural distance. The Kogut-Singh index is a composite index based on Hofstede’s (1980) four cultural dimensions (power distance, uncertainty avoidance, individualismcollectivism, and masculinity-femininity), and gives a metric for the cultural distance between Denmark 
and the various foreign markets. Geographical distance was captured by a dummy variable indicating whether the foreign market was in Europe or outside Europe.

The operationalization of the explanatory variables is summarized in Table 3. Examination of the correlation matrix (see table in appendix) shows that none of the exogenous variables are highly correlated ${ }^{5}$. Descriptive statistics (mean and standard deviation) on each of the explanatory variables are also included in the table in the appendix.

****Table 3 about here ${ }^{* * * *}$

\section{Model Specification and Estimation Results}

The model was estimated by logistic regression analysis with a binary response variable; "no switch" and "switch of operation mode" were coded as 0 and 1, respectively. Suppose $\mathbf{x}$ is a vector of explanatory variables and $p$ is the probability of the response to be modelled (in this case the probability of switch of entry mode). The estimated logistic model has the form:

$$
\operatorname{logit}(p)=\log [p /(1-p)]=a+\boldsymbol{B} \mathbf{x}
$$

where $a$ is the intercept parameter, and $\boldsymbol{B}$ is the vector of slope parameters. The Proc Logistic program in SAS (1990) was used to estimate the model. The estimated model has a chi-square value for the covariates of 76.4 (14 d.f.) which is highly significant ( $p=0.0001$ ). The null hypothesis that $\boldsymbol{B}=0$ is hence rejected. Including the covariates in the model reduces the variation from 180.6 to 104.2 which gives a pseudo- $R^{2}=$ 42.3. This indicates that the explanatory variables explain more than forty per cent of the variation in the response variable. Another goodness-of-fit statistic is the so-called Pearson deviance. The null hypothesis is that the predicted values are significantly different from the observed values of the response variable. The calculated Pearson deviance is 0.55 (199 d.f., $p=0.93$ ), which indicates that the model gives a very

5 Only one moderately high correlation was found; between "market growth" and "cultural distance" $(r=0.54)$. Excluding one or the other variable from the regressions did not change any of the results, which indicates that 
good description of the observed changes in foreign operation method. Moreover, 83 per cent of the observations are classified correctly by the model. The estimation results are reported in table 4 .

****Table 4 about here****

\section{RESULTS AND DISCUSSION}

It appears from the results that the prediction of mode shifts is to be found in an interplay between, on the one side, changes of organizational and environmental conditions, and, on the other side, the switching costs associated with a shift. As such, the mode shift decision seems to implicate a cost-benefit analysis. In our data, the switching costs variables appear to have the upper hand in terms of explaining the incidence of entry mode shifts.

All hypotheses regarding switching costs $\left(\mathrm{H}_{5}\right.$ to $\left.\mathrm{H}_{8}\right)$ are supported by the data in this study. The perceived switching costs in relation to recruitment and training have a particular strong, and negative, influence on the exporters' inclination to convert their foreign intermediaries into sales subsidiaries and/or home-based salesforces $\left(B_{7}=-1.188, p<0.01\right)$. The importance of this set-up switching cost mirrors the finding reported in an earlier mode-shift study by Weiss and Anderson (1992). The assertion that lack of international experience may act as a set-up impediment to change is also supported $\left(B_{8}=-0.023, p<\right.$ 0.10). However, in contrast to the results reported by Weiss and Anderson (1992), the present study suggests that take-down costs in the form of long notice of termination $\left(B_{5}=-1.855, p<0.01\right)$ - with the associated risk of demands of severance payment in case of infringements - as well as potential loss of sales revenue $\left(B_{6}=-1.058, p<0.10\right)$ also have a negative effect on exporters' propensity to make mode shifts. Two of the four impetus-to-switch factors (the so-called "change aspects”) come out significant; "satisfaction with the intermediary" $\left(B_{1}=0.612, p<0.05\right)$ and exporters' accumulation of market knowledge $\left(B_{2}=0.647, p<0.10\right)$. Hypotheses $\mathrm{H}_{1}$ and $\mathrm{H}_{2}$ therefore, gain support. While the first result is in accordance with the findings of Weiss and Anderson (1992), our finding that exporters' accumulation

the results are not seriously affected by collinearity problems. 
of market knowledge has a positive, rather than a negative, effect on the likelihood of mode shifts goes against Weiss and Anderson's theoretical as well as empirical analysis.

From a theoretical perspective, the latter finding is of particular interest because competing predictions are proposed by the economics (transaction cost economics) and behavioral (internationalization process) approaches, respectively. Our finding questions the assumption made in transaction cost economics that relationship longivety should decrease the motivation to switch (Williamson, 1985). According to Williamson, the longer a relationship lasts the more asset specificity the parties will develop, and as a result the more they get “locked-in” into the relationship. This suggests that switching costs are likely to increase as a relationship continues. Consequently, as a relationship evolves the likehood of a mode shift should decrease. Our findings, on the other hand, indicate that the propensity to switch actually increases the longer the exporters have been in a given market (with a given distributor or agent), which is in accordance with the assertation made by internationalization process theory that over time firms become more willing and prepared to engage themselves in market servicing modes that entail a higher degree of resources and commitment ${ }^{6}$.

Apart from company size that showed a statistically significant, albeit weak, association with change of operation method $\left(B_{11}=0.752, p<0.10\right)$, the remaining variables concerning sales volume (“export market growth” and "export market potential”), monitoring problems, product type, and cultural/geographical distance did not have any statistically significant effect on the likelihood of mode shifts.

\section{CONCLUSION AND SUGGESTIONS FOR FURTHER RESEARCH}

Shift of operation mode makes up an integral part of internationalization process theory. As the perceived uncertainty associated with foreign business operations is reduced firms are predicted to switch to higher commitment operation modes (Johanson and Vahlne, 1977). To the extent that the entrant firm has sufficient knowledge about how to do business in the foreign market, the shift per se is assumed to take

\footnotetext{
${ }^{6}$ For a discussion of this theoretical controversy, see Benito et al. (1999).
} 
place unhindered. The present study suggests that this (implicit) assumption needs caution. Even if entrant firms have acquired all the knowledge required to perform in-house operations in foreign markets the firms might still retain their existing operation mode arrangements because of the prospective take-down switching costs (contractual restrictions, loss of customers). Using data from a sample of Danish exporting companies, this study finds that within the observed five-year period one out of six exporters completed a shift from using an independent intermediary to establishing an employee sales organization in order to serve foreign markets. This observation confirms that shift of operation mode is far from being a rarity. On the other hand, the study also suggests that considerably more exporters would have completed shifts in the absence of potential switching costs. In addition to take-down costs, expenses in establishing in-house operations (set-up switching costs) were also found to be important. Thus, recruitment \& training costs and foreign operation learning costs seem to constitute significant barriers to mode shifts, and - in accordance with internationalization process theory - point to the considerable risk associated with inhouse operations in unfamiliar, foreign markets. All told, the study indicates that the concept of switching costs deserves more research attention than hitherto given.

Being among the first to investigate foreign market servicing decisions in a longitudinal perspective, this study has an exploratory character and the results should therefore be regarded as tentative. While several limitations should be noted, the very same limitations open interesting avenues for future research. First, although the reasoning underlying the framework presented here was by and large supported by the empirical analysis, some hypotheses failed to receive statistical support. Somewhat crude measurements may have had some part in this. In particular, GNP and growth in GNP are rather imprecise proxies for market size and market growth, and efforts should be made in future studies to collect data on more disaggregated levels. Also, multi-item measures on multifaceted variables such as accumulation of market knowledge would increase measurement reliability. Second, the present study focuses on one particular type of change of foreign operation method, namely the transition from independent to integrated marketing channels. We believe that our framework captures essential elements of decisions regarding other changes of foreign operation methods as well - say, for example, the replacement of a licensing agreement with foreign direct investment in manufacturing. But, of course, it is an open question 
to what extent our framework is applicable to other contexts. Future research may look at ways to improve the framework conceptually, enlarge the framework by including factors other than those studied here, as well as make more specific adjustments to the actual problems and contexts under study. Finally, the findings presented here pertain to the behavior of a particular sample of Danish exporters, and future studies should examine to what extent our findings can be generalized to other empirical settings.

Switching costs are of particular interest from a managerial point of view. After all, such costs constitute a hindrance to conversions to more efficient institutional arrangements. It seems probable, however, that switching costs could be reduced through careful planning by the exporting company. Such planning may include buy-out options, operation mode combinations, and joint ventures (Petersen, Welch and Welch, 2000). Preferably, the entrant firm should put into place the means to avoid switching costs already in the initial agreement with the local operator. One of the findings of the present study is that firms are more likely to carry out mode shifts as they increase their international experience. That finding suggests that managers, as part of the internationalization process, are able to develop various methods to reduce or eliminate potential switching costs. A natural extension of this study is therefore to take a closer look at changes of foreign operation methods in order to detect effective precautions - as practiced by internationally experienced companies - against switching costs. The insights gained from such studies should be of considerable interest to internationalizing firms and to those responsible for assistance programs aimed at such firms.

\section{REFERENCES}

Ali, A.J. and R.C. Camp (1993). The relevance of firm size and international business experience to market entry strategies. Journal of Global Marketing, 6(4), 91-108.

Anderson, E. and A.T. Coughlan (1987). International market entry and expansion via independent or integrated channels of distribution. Journal of Marketing, 51(1), 71-82.

Anderson, E. and H. Gatignon (1986). Modes of foreign entry: A transaction cost analysis and propositions. Journal of International Business Studies, 17(3), 1-26.

Anderson, E. and R.L. Oliver (1987). Perspectives on behavior-based and outcome-based salesforce control systems. Journal of Marketing, 51(3), 76-88. 
Anderson, J.C. and J.A. Narus (1990). A model of distributor firm and manufacturing firm working partnerships. Journal of Marketing, 54(1), 42-58.

Barkema, H. G., J. Bell, and J. M. Pennings (1996). Foreign entry, cultural barriers, and learning. Strategic Management Journal, 17, 151-166.

Benito, G.R.G., T. Pedersen, and B. Petersen (1999). Foreign operation methods and switching costs: Conceptual issues and possible effects. Scandinavian Journal of Management, 15(2), 213-229.

Benito, G.R.G. and L.S. Welch (1994). Foreign market servicing: Beyond choice of entry mode. Journal of International Marketing, 2(2), 7-27.

Björkman, I. and M. Eklund (1996). The sequence of operational modes used by Finnish investors in Germany. Journal of International Marketing, 4(1), 33-35.

Buckley, P.J. and M.C. Casson (1985). The economic theory of the multinational enterprise. London: Macmillan.

Calof, J.L. (1993). The mode choice and change decision process and its impact on international performance. International Business Review, 2(1), 97-120.

Calof, J.L. and P.W. Beamish (1995). Adapting to foreign markets: Explaining internationalization. International Business Review, 4(2), 115-131.

Caves, R.E. and M.E. Porter (1977). From entry barriers to mobility barriers: Conjectural decisions and contrived deterrence to new competition. Quarterly Journal of Economics, 91(2), 241-261.

Corey, E.R., F.V. Cespedes, and V.K. Rangan (1989). Going to market - distribution systems for industrial products. Boston Massachusetts: Harvard Business School Press.

Fina, E. and A. M. Rugman (1996). A test of internalization theory and internationalization theory: The Upjohn Company. Management International Review, 36(3), 199-213.

Gomes-Casseres, B. (1987). Joint venture instability: Is it problem? Columbia Journal of World Business, Summer, 97-102.

Hannan, M.T. and J. Freeman (1984). Structural inertia and organizational change. American Sociological Review, 49, 149-164.

Hedlund, G. and Å. Kverneland (1985). Are strategies for foreign markets changing? The case of Swedish investment in Japan. International Studies of Management and Organization, 15(2), 41-59.

Heide, J. and G. John (1988). The role of dependence balancing in safeguarding transaction-specific assets in conventional channels. Journal of Marketing, 52(1), 20-35.

Hennart, J.-F. (1991). Control in multinational firms: The role of price and hierarchy. Management International Review, 31(Special Issue), 71-96.

Hill, C.W.L., P. Hwang and W.C. Kim (1990). An eclectic theory of the choice of international entry mode. Strategic Management Journal, 11(2), 117-128.

Hofstede, G. (1980). Culture's consequences: International differences in work-related values. Beverly Hills, CA: Sage Publications. 
Jackson, B.B. (1985). Winning and keeping industrial customers: The dynamics of customer relationships. Lexington, MA: Lexington Books.

Johanson, J. and J.-E. Vahlne (1977). The internationalization process of the firm: A model of knowledge development and increasing foreign market commitment. Journal of International Business Studies, 8(1), 23-32.

Johanson, J. and F. Wiedersheim-Paul (1975). The internationalization of the firm: Four Swedish cases. Journal of Management Studies, 12(3), 305-322.

Klein, S., G.L. Frazier and V.J. Roth (1990). A transaction cost analysis model of channel integration in international markets. Journal of Marketing Research, 27(2), 196-208.

Klemperer, P. (1987). The competitiveness of markets with switching costs. Rand Journal of Economics, 18(1), 138-150.

Kogut, B. and H. Singh (1988). The effect of national culture on the choice of entry mode. Journal of International Business Studies, 19, 411-432.

Leonidou, L.C. and C.S. Katsikeas (1996). The export development process: An integrative review of empirical models. Journal of International Business Studies, 27(3), 517-551.

Madhok, A. (1997). Cost, value and foreign market entry mode: The transaction and the firm. Strategic Management Journal, 18(1), 39-61.

Penrose, E. (1956). Foreign investment and the growth of the firm. In M. Wilkins (ed.) The growth of multinationals. Vermont, USA: Edward Elgar Publishing Company, 1991 (originally in The Economic Journal, June 1956).

Penrose, E. (1959). The theory of the growth of the firm. London: Basil Blackwell.

Petersen, B. (1996). Explaining cost-effective export market penetration via foreign intermediaries. Copenhagen: Copenhagen Business School, Ph.D. series 4.96.

Petersen, B., D.E. Welch and L.S. Welch (2000). Creating meaningful switching options in international operations. Long Range Planning, forthcoming.

Root, F.R. (1987). Entry strategies for international markets. Lexington, MA: Lexington Books.

Rosson, P.J. (1984). Success factors in manufacturer-overseas distributor relationships in international marketing. In K. Erdener (ed.) International marketing management. New York: Praeger.

Rosson, P.J. (1987). The overseas distribution method: Performance and change in a harsh environment. In P.J. Rosson and S.D. Reid (eds.) Managing export entry and expansion, New York: Praeger.

SAS (1990). SAS technical report P-200 - CALIS and LOGISTIC procedures. North Carolina: SAS Institute Inc.

Shamdasani, P.N. and J.N. Sheth (1995). An experimental approach to investigating satisfaction and continuity in marketing alliances. European Journal of Marketing, 29(4), 6-23.

Stern, L.W. and A.I. El-Ansary (1992). Marketing channels. (4th ed.) Englewood Cliffs, New Jersey: 


\section{Prentice-Hall.}

Weiss, A.M. and E. Anderson (1992). Converting from independent to employee salesforce: The role of perceived switching costs. Journal of Marketing Research, 29(1), 101-115.

Welch, L.S. and R.K. Luostarinen (1988). Internationalization: Evolution of a concept. Journal of General Management, 14(2),34-55.

Welch, L.S. and F. Wiedersheim-Paul (1980). Initial exports - a marketing failure? Journal of Management Studies, 17(3), 333-344.

Williamson, O.E. (1985). The economic institutions of capitalism: firms, markets, relational contracting. New York: The Free Press. 
Table 1. Changes of foreign market servicing method from 1992 to 1997.

\begin{tabular}{|c|c|c|c|}
\hline \multicolumn{3}{|c|}{ Categories } & No. of case \\
\hline a. & $\begin{array}{l}\text { No switch in entry mode since } 1992 \text { (still independent } \\
\text { intermediary): }\end{array}$ & 230 & \\
\hline & $\begin{array}{l}\text { - served by the same intermediary as in } 1992 \\
\text { • had shifted intermediary (but not changed entry mode) } \\
\text { • no switch but established "dual distribution" }\end{array}$ & & $\begin{array}{r}182 \\
42 \\
6\end{array}$ \\
\hline$b$. & Intended to switch entry mode in the near future & 10 & \\
\hline c. & Had switched entry mode since 1992 & 36 & \\
\hline Total & & & 276 \\
\hline
\end{tabular}

Table 2. Geographical distribution of the sample and switching rates by 1997.

\begin{tabular}{lccc}
\hline Countries/regions & $\begin{array}{c}\text { Number of } \\
\text { intermediaries in } \\
1992\end{array}$ & $\begin{array}{c}\text { Number of shifts to } \\
\text { ”in-house” } \\
\text { operations }\end{array}$ & $\begin{array}{c}\text { Switching rates in } \\
\text { percent }\end{array}$ \\
\hline $\begin{array}{l}\text { Europe: } \\
\quad \text { Nordic countries }\end{array}$ & 33 & 2 & 6.1 \\
$\quad$ Germany & 51 & 9 & 17.7 \\
$\quad$ UK and Ireland & 23 & 3 & 13.0 \\
$\quad$ Rest of Europe & 54 & 11 & 20.3 \\
North-America & 19 & 3 & 15.8 \\
Rest of the world & 34 & 4 & 11.8 \\
& & & 15.0 \\
\hline
\end{tabular}


Table 3. Description of independent variables and data sources.

\begin{tabular}{llc}
\hline Variable & Measurement & Data source* \\
\hline
\end{tabular}

\section{Switching motivators}

1. Diminishing satisfaction

2. Accumulation of market knowledge

3. Growth of market

4. Growth of company
How does the company perceive the succes of the intermediary in terms of $i$ ) market penetration, $i$ ) profitability of export and iii) the effort made? (Likertscale: 1 = very satisfactory, 7 = very dissatisfactory)

Log of number of years since the company made the first agreement with a foreign intermediary in the market Growth in GNP (in USD) from 1991 to 1995 in the particular market

Growth in employment from 1991 to 1995
Questionnaire

Interview

World Marketing Data and Statistics 1997

CD-Direct's database on Danish companies

Questionnaire advance in case of termination of the agreement Is the foreign intermediary taking care of after-sales activities? (dummy: $0=$ yes, $1=$ no)

\section{Switching costs}

\section{Contractual} restrictions

6. Loss of sales revenue

7. Recruitment and training costs

8. International experience

What would be the costs if the company had to recruit and train its own sales force for the particular market? (Likert-scale: 1 = expecting minimal costs, 7 = expecting huge costs)

The share of total turnover sold on the Danish home market

\section{Control variables}

9. Monitoring problems

10. Market potential

How difficult is it to monitor the effort of the intermediary? (Likert-scale: 1 = rather simple, 7 = very difficult)

GNP in 1991 (in billion US \$) in the particular market

11. Company size

Employment in 1991 (in 1,000)

12. Product type

13. Cultural distance

14. Geographical distance
Dummy variable ( 0 = industrial product, $1=$ consumer product), based on ISIC classification

Kogut-Singh index
Questionnaire

Questionnaire/

Interview

CD-Direct's database on Danish companies

Questionnaire

World Marketing Data and Statistics 1997

CD-Direct's database on Danish companies CD-Direct's database on Danish companies Own calculations based on questionnaire data Interview

Note: * The questionnaire data were collected in 1992 and the (telephone) interviews were conducted in 1997. 
Table 4. Overall model results: Logistic regression estimation (+ = higher probability of switch).

\begin{tabular}{lrll}
\hline Variables & $\begin{array}{r}\text { Parameter } \\
\text { estimate }\left(B_{\mathrm{i}}\right)\end{array}$ & Standard error \\
\hline 1. Diminishing satisfaction & 0.612 & $0.274^{* *}$ \\
2. Accumulation of market knowledge & 0.647 & $0.336^{*}$ \\
3. Export market growth & 0.009 & 0.018 \\
4. Growth of exporting company & 0.005 & 0.008 \\
5. Contractual restrictions & -1.855 & $0.664^{* * *}$ \\
6. Loss of export sales revenue & -1.058 & $0.585^{*}$ \\
7. Recruitment and training costs & -1.188 & $0.256^{* * *}$ \\
8. Lack of international experience & -0.023 & $0.013^{*}$ \\
9. Monitoring problems & -0.041 & 0.179 \\
10. Export market potential & -0.269 & 0.652 \\
11. Company size & 0.752 & $0.395^{*}$ \\
12. Product type & -0.035 & 0.556 \\
13. Cultural distance & -0.074 & 0.190 \\
14. Geographical distance & 1.086 & 0.805 \\
& & \\
\hline
\end{tabular}

Note: $* * *, * *$, and $*$, denote significance at $1 \%, 5 \%$, and $10 \%$ levels, respectively (two-tailed tests). 
APPENDIX: Correlation matrix ( $p$-values in parentheses) and descriptive statistics

$\begin{array}{rrrrrrrrrrrrr}1 . & 2 . & 3 . & 4 . & 5 . & 6 . & 7 . & 8 . & 9 . & 10 . & 11 . & 12 .\end{array}$

\begin{tabular}{|c|c|c|c|c|c|c|c|c|c|c|c|c|c|c|}
\hline 1. Satisfaction & 1.00 & & & & & & & & & & & & & \\
\hline 2. Knowledge & $\begin{array}{l}-0.12 \\
(0.07)^{*}\end{array}$ & 1.00 & & & & & & & & & & & & \\
\hline 3. Market growth & $\begin{array}{l}-0.03 \\
(0.71)\end{array}$ & $\begin{array}{c}0.01 \\
(0.88)\end{array}$ & 1.00 & & & & & & & & & & & \\
\hline 4. Company growth & $\begin{array}{l}-0.03 \\
(0.66)\end{array}$ & $\begin{array}{l}-0.07 \\
(0.30)\end{array}$ & $\begin{array}{l}0.14 \\
(0.04)^{* *}\end{array}$ & 1.00 & & & & & & & & & & \\
\hline $\begin{array}{l}\text { 5. Contractual } \\
\text { restrictions }\end{array}$ & $\begin{array}{l}-0.10 \\
(0.16)\end{array}$ & $\begin{array}{l}-0.07 \\
(0.34)\end{array}$ & $\begin{array}{l}-0.07 \\
(0.31)\end{array}$ & $\begin{array}{l}-0.01 \\
(0.92)\end{array}$ & 1.00 & & & & & & & & & \\
\hline 6. Loss of sales & $\begin{array}{l}0.06 \\
(0.41)\end{array}$ & $\begin{array}{l}0.06 \\
(0.36)\end{array}$ & $\begin{array}{l}-0.04 \\
(0.51)\end{array}$ & $\begin{array}{l}-0.04 \\
(0.55)\end{array}$ & $\begin{array}{c}0.11 \\
(0.10)\end{array}$ & 1.00 & & & & & & & & \\
\hline 7. Training costs & $\begin{array}{l}0.04 \\
(0.54)\end{array}$ & $\begin{array}{l}-0.01 \\
(0.85)\end{array}$ & $\begin{array}{l}-0.05 \\
(0.43)\end{array}$ & $\begin{array}{l}-0.04 \\
(0.57)\end{array}$ & $\begin{array}{l}0.12 \\
(0.08)^{*}\end{array}$ & $\begin{array}{c}0.05 \\
(0.43)\end{array}$ & 1.00 & & & & & & & \\
\hline 8. Lack of experience & $\begin{array}{l}0.06 \\
(0.40)\end{array}$ & $\begin{array}{l}-0.08 \\
(0.22)\end{array}$ & $\begin{array}{l}-0.12 \\
(0.09) *\end{array}$ & $\begin{array}{l}-0.11 \\
(0.13)\end{array}$ & $\begin{array}{c}0.10 \\
(0.16)\end{array}$ & $\begin{array}{l}-0.12 \\
(0.09)^{*}\end{array}$ & $\begin{array}{c}0.10 \\
(0.16)\end{array}$ & 1.00 & & & & & & \\
\hline 9. Monitoring & $\begin{array}{l}0.16 \\
(0.02)^{* *}\end{array}$ & $\begin{array}{l}-0.02 \\
(0.80)\end{array}$ & $\begin{array}{l}0.14 \\
(0.04)^{* *}\end{array}$ & $\begin{array}{l}-0.04 \\
(0.56)\end{array}$ & $\begin{array}{l}-0.13 \\
(0.06)^{*}\end{array}$ & $\begin{array}{l}-0.01 \\
(0.93)\end{array}$ & $\begin{array}{l}-0.09 \\
(0.19)\end{array}$ & $\begin{array}{l}-0.05 \\
(0.48)\end{array}$ & 1.00 & & & & & \\
\hline $\begin{array}{l}\text { 10. Market } \\
\text { potential }\end{array}$ & $\begin{array}{l}0.01 \\
(0.93)\end{array}$ & $\begin{array}{c}0.03 \\
(0.62)\end{array}$ & $\begin{array}{l}-0.003 \\
(0.96)\end{array}$ & $\begin{array}{l}0.13 \\
(0.05)^{*}\end{array}$ & $\begin{array}{r}0.001 \\
(0.99)\end{array}$ & $\begin{array}{c}0.04 \\
(0.55)\end{array}$ & $\begin{array}{c}0.07 \\
(0.31)\end{array}$ & $\begin{array}{l}-0.05 \\
(0.51)\end{array}$ & $\begin{array}{l}-0.02 \\
(0.76)\end{array}$ & 1.00 & & & & \\
\hline 11. Company size & $\begin{array}{l}-0.03 \\
(0.69)\end{array}$ & $\begin{array}{l}-0.05 \\
(0.44)\end{array}$ & $\begin{array}{l}-0.05 \\
(0.49)\end{array}$ & $\begin{array}{l}-0.04 \\
(0.58)\end{array}$ & $\begin{array}{l}-0.03 \\
(0.62)\end{array}$ & $\begin{array}{l}-0.01 \\
(0.91)\end{array}$ & $\begin{array}{l}-0.12 \\
(0.07) *\end{array}$ & $\begin{array}{l}-0.11 \\
(0.12)\end{array}$ & $\begin{array}{l}-0.01 \\
(0.84)\end{array}$ & $\begin{array}{l}-0.01 \\
(0.95)\end{array}$ & 1.00 & & & \\
\hline 12. Product type & $\begin{array}{l}0.02 \\
(0.30)\end{array}$ & $\begin{array}{l}-0.02 \\
(0.83)\end{array}$ & $\begin{array}{l}0.02 \\
(0.77)\end{array}$ & $\begin{array}{l}-0.08 \\
(0.27)\end{array}$ & $\begin{array}{l}0.05 \\
(0.49)\end{array}$ & $\begin{array}{l}-0.09 \\
(0.19)\end{array}$ & $\begin{array}{l}-0.11 \\
(0.12)\end{array}$ & $\begin{array}{l}0.21 \\
(0.01)^{* * *}\end{array}$ & $\begin{array}{l}-0.10 \\
(0.14)\end{array}$ & $\begin{array}{l}-0.03 \\
(0.66)\end{array}$ & $\begin{array}{c}0.09 \\
(0.20)\end{array}$ & 1.00 & & \\
\hline $\begin{array}{l}\text { 13. Cultural } \\
\text { distance }\end{array}$ & $\begin{array}{l}-0.07 \\
(0.30)\end{array}$ & $\begin{array}{c}0.01 \\
(0.89)\end{array}$ & $\begin{array}{l}0.54 \\
(0.01)^{* * *}\end{array}$ & $\begin{array}{c}0.09 \\
(0.20)\end{array}$ & $\begin{array}{l}-0.15 \\
(0.03)^{* *}\end{array}$ & $\begin{array}{l}-0.04 \\
(0.59)\end{array}$ & $\begin{array}{l}-0.10 \\
(0.13)\end{array}$ & $\begin{array}{l}-0.18 \\
(0.01)^{* * *}\end{array}$ & $\begin{array}{l}0.09 \\
(0.20)\end{array}$ & $\begin{array}{c}0.05 \\
(0.44)\end{array}$ & $\begin{array}{l}0.26 \\
(0.01)^{* * *}\end{array}$ & $\begin{array}{c}0.04 \\
(0.56)\end{array}$ & 1.00 & \\
\hline $\begin{array}{l}\text { 14. Geographical } \\
\text { distance }\end{array}$ & $\begin{array}{l}0.04 \\
(0.54)\end{array}$ & $\begin{array}{l}0.02 \\
(0.79)\end{array}$ & $\begin{array}{l}-0.36 \\
(0.01)^{* * *}\end{array}$ & $\begin{array}{l}-0.07 \\
(0.31)\end{array}$ & $\begin{array}{l}0.18 \\
(0.01)^{* *}\end{array}$ & $\begin{array}{l}0.07 \\
(0.33)\end{array}$ & $\begin{array}{l}-0.09 \\
(0.19)\end{array}$ & $\begin{array}{l}0.16 \\
(0.02)^{* *}\end{array}$ & $\begin{array}{l}-0.02 \\
(0.78)\end{array}$ & $\begin{array}{l}-0.21 \\
(0.01)^{* * *}\end{array}$ & $\begin{array}{l}-0.01 \\
(0.86)\end{array}$ & $\begin{array}{c}0.12 \\
(0.07)^{*}\end{array}$ & $\begin{array}{l}-0.37 \\
(0.01)^{* * *}\end{array}$ & 1.00 \\
\hline Mean & 2.46 & 2.05 & 25.30 & 25.32 & 2.15 & 1.78 & 4.80 & 26.03 & 2.99 & 0.14 & 0.18 & 0.30 & 2.98 & 0.78 \\
\hline Standard deviation & 0.99 & 0.89 & 17.94 & 33.30 & 0.52 & 0.42 & 1.72 & 22.84 & 1.44 & 0.65 & 0.51 & 0.46 & 1.81 & 0.41 \\
\hline
\end{tabular}

Note: ***, **, and ${ }^{*}$, denote significance at $1 \%, 5 \%$ and $10 \%$ levels, respectively. 